International Journal of Current Advanced Research

ISSN: O: 2319-6475, ISSN: P: 2319 - 6505, Impact Factor: SJIF: 5.995

Available Online at www.journalijcar.org

Volume 6; Issue 5; May 2017; Page No. 3582-3583

DOI: http://dx.doi.org/10.24327/ijcar.2017.3583.0320

Research Article

\title{
MORPHOMETRIC STUDY OF NUTRIENT FORAMINA IN THE DRY HUMAN RADII
}

\author{
SaiSandhya.T and Karpagam
}

Saveetha Dental College, Chennai, Tamil Nadu, India

\begin{tabular}{|c|c|}
\hline A R T I C L E I N F O & A B S T R A C T \\
\hline Article History: & Aim: To study the morphology of nutrient foramina in the dry human radii. \\
\hline Received $17^{\text {th }}$ February, 2017 & $\begin{array}{l}\text { Objective: To study the location, direction of nutrient foramina of dry human radii and its } \\
\text { significance during orthonaedic surgeries. }\end{array}$ \\
\hline Received in revised form $12^{\text {th }}$ March, 2017 & Background: The radius or radial bone is one of the two large bones of the forearm, the \\
\hline Published online $28^{\text {th }}$ May, 2017 & $\begin{array}{l}\text { other being the ulna. The radius bone extends from the lateral side of the elbow to the } \\
\text { thumb side of the wrist and runs parallel to the ulna, which exceeds it in length and size. It }\end{array}$ \\
\hline Key words: & joints, the elbow and the wrist. At the elbow, it joins with the capitulum of the humerus and \\
\hline $\begin{array}{l}\text { Nutrient Foramina, } \\
\text { Radius Bone, Ulna Bone }\end{array}$ & $\begin{array}{l}\text { in a separate region with the ulna at the radial notch. At the wrist the radius forms a joint } \\
\text { with the ulna bone }\end{array}$ \\
\hline
\end{tabular}

Copyright $\bigcirc 2017$ SaiSandhya.T and Karpagam. This is an open access article distributed under the Creative Commons Attribution License, which permits unrestricted use, distribution, and reproduction in any medium, provided the original work is properly cited.

\section{INTRODUCTION}

Bones are the structures that adapt to their mechanical environment and from a fetal age adapt to the presence of naturally occurring holes[1] .Radius [fore arm bone] lies by the side of ulna on outer side of fore arm[2]. The upper part of bone presents a nutrient canal which transmits nutrient artery[3]. Nutrient canal is directed upwards in radius [4]. The nutrient artery is the principle source of blood supply to a long bone and is particularly important during its active growth period in the embryo and fetus as well as during the early phase of ossification [5]. During childhood, the nutrient arteries provide $70 \%$ to $80 \%$ of the interosseous blood supply to long bones[6]. It has been suggested that the direction of the nutrient foramina is determined by the growing end of the bone[7]. The topographical knowledge of these nutrient foramina is useful in operative procedures to preserve the circulation[8]. The aim of the present investigation is to study the morphology of nutrient foramina in the dry human radius bone.

\section{MATERIALS AND METHODS}

The study was conducted in The Department of Anatomy, Saveetha University, Chennai. 35 dry human radii was were selected for the study, of which 15 were right radii and 20 were left radii [1]. Bones were cleaned thoroughly. The bones, which had gross pathological deformities, damaged and unossified were excluded from the study [2].

*Corresponding author: SaiSandhya.T

Saveetha Dental College, Chennai, Tamil Nadu, India
The nutrient foramina were observed in all the bones with help of a hand lens [3]. They were identified by their elevated margins and by the presence of a distinct groove proximal to them [4]. The distance of nutrient foramina from its upper end and lower end were measured with the help of a sliding vernier calipe [5]r. The average distances from upper and lower ends are tabulated separately for right and left radius bones.[6]

\section{RESULTS AND DISCUSSION}

From the bones observed, there is no accessory foramen.

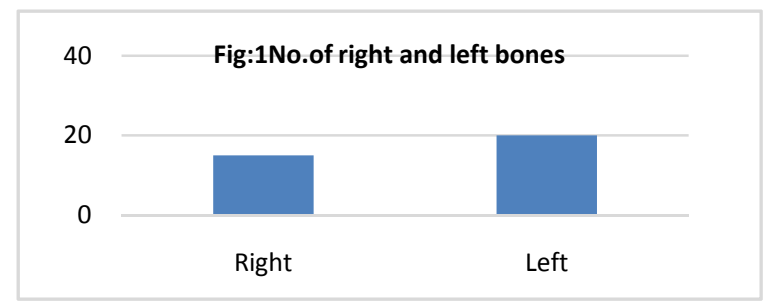

Figure 1 Shows the number of right and left bones observed

Fig:2 average distances from upper and lower ends in left radius bone

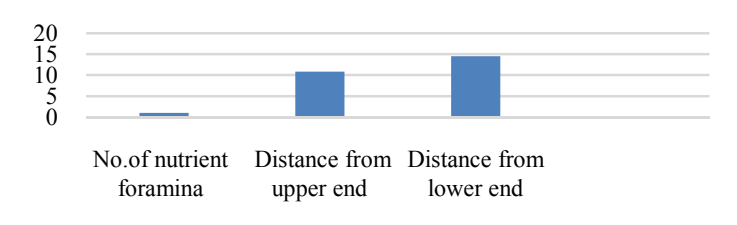

Figure 2 Shows the distance of the nutrient foramina from the upper and lower end of the left Radius bones observed. 


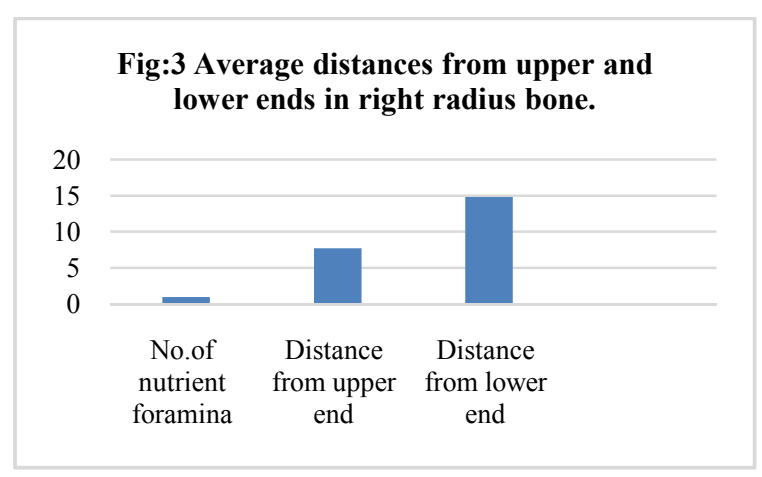

Figure 3 Shows the distance of the nutrient foramina from the upper and lower end of the right Radius bones observed

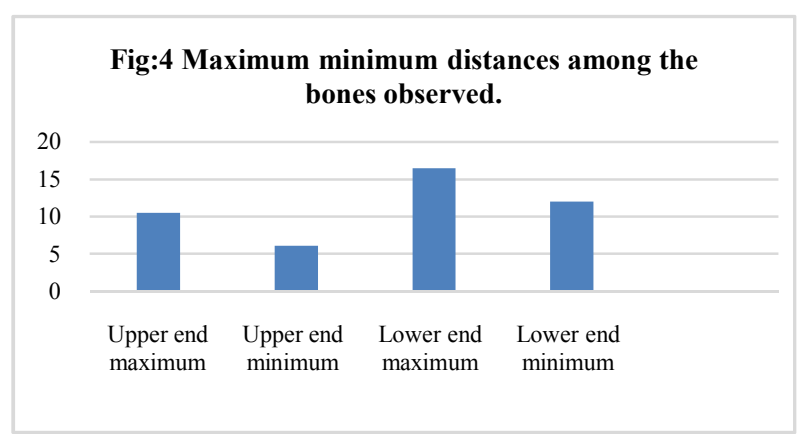

Figure 4 Shows the maximum and minimum distances of the nutrient foramina from the bones Observed.

Maximum distance measured from the upper end is- $10.5 \mathrm{~cm}$.

Minimum distance measured from the upper end is- $6.1 \mathrm{~cm}$.

Maximum distance measured from the lower end is- $16.5 \mathrm{~cm}$.

Minimum distance measured from the lower end is- $12 \mathrm{~cm}$.

\section{CONCLUSION}

The knowledge about the nutrient foramina is useful in certain surgical procedures to preserve the circulation. Any orthopaedic surgery needs a thorough knowledge about the anatomy of the bone. Nutrient foramina and its position is very important to retain and maintain the nourishment of the bone. So, the position of the foramina and its study is very important in any orthopaedic surgery.

\section{References}

1. Morphological and topographical anatomy of the nutrient formina in human upper limb long bones and their surgical importance. Murlimanju B.V, Prashanth K.U, Prabhu L.V, Saralaya .V.V R

2. Essentials of human anatomy, A.K. Dutta.

3. Diaphyseal nutrient foramina in human long bones, Mysorekar.V.R J.Anat 1967 Sep;101[PT4] : 813-22

4. Morphological variations of nutrient foramina in the upper limb long bones, M.Sharma, R.Prashar, T.Sharma 2013

5. Analytical and morphometric study of nutrient foramina of femurs in Rohilkhand region by R Kumar,

6. A study of nutrient foramina in long bones of Nigerians.

7. Morphometric study of nutrient foramina of human radii in telengana region.

\section{How to cite this article:}

SaiSandhya.T and Karpagam (2017) ' Morphometric Study Of Nutrient Foramina In The Dry Human Radii', International Journal of Current Advanced Research, 06(05), pp. 3582-3583.

DOI: http://dx.doi.org/10.24327/ijcar.2017.3583.0320 